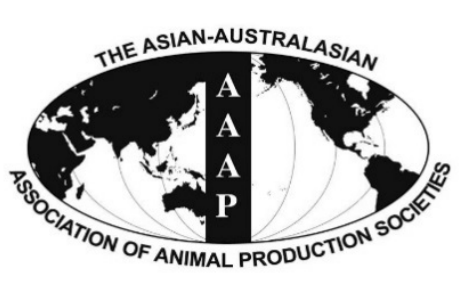

Open Access

Asian Australas. J. Anim. Sci.

Vol. 29, No. 9 : 1265-1272 September 2016

http://dx.doi.org/10.5713/ajas.16.0099

www.ajas.info

pISSN 1011-2367 elSSN 1976-5517

\title{
Effects of Different Cutting Height on Nutritional Quality of Whole Crop Barley Silage and Feed Value on Hanwoo Heifers
}

\author{
Dong Hyeon Kim ${ }^{1}$, Sardar M. Amanullah ${ }^{1,2}$, Hyuk Jun Lee', Young Ho Joo', \\ Ouk Kyu Han ${ }^{3}$, Adegbola T. Adesogan ${ }^{4}$, and Sam Churl Kim ${ }^{1, *}$ \\ ${ }^{1}$ Division of Applied Life Science (BK21Plus, Institute of Agriculture and Life Science), \\ Gyeongsang National University, Jinju 52828, Korea
}

\begin{abstract}
The present study evaluated the effects of different cutting height on nutritive value, fermentation quality, in vitro and in vivo digestibility of whole crop barley silage. Whole crop barley forage (Yuyeon hybrid) was harvested at height of 5, 10, and $15 \mathrm{~cm}$ from the ground level. Each cutting height was rolled to make round bale and ensiled for 100 days. After 100 days of ensiling, $\mathrm{pH}$ of silage was lower $(\mathrm{p}<0.05)$ in $5 \mathrm{~cm}$, but no difference between 10 and $15 \mathrm{~cm}$ of cutting height. The content of lactate and lactate to acetate ratio were increased $(\mathrm{p}<0.05)$ in $5 \mathrm{~cm}$ of cutting height, whereas the acetate content was higher $(\mathrm{p}<0.05)$ in 10 and $15 \mathrm{~cm}$ than that of $5 \mathrm{~cm}$ cutting height. Aerobic stability was greater $(\mathrm{p}<0.05)$ in silages of 10 and $15 \mathrm{~cm}$ of cutting height. Three total mixed rations (TMR) were formulated with silages from the three different cutting heights (TMR5, TMR10, and TMR15) incorporated as forage at 70:30 ratio with concentrate (dry matter [DM] basis). In vitro dry matter digestibility was higher $(\mathrm{p}<0.05)$ in the TMR5 and TMR10 than that in TMR15, whereas in vitro neutral detergent fiber digestibility was higher $(\mathrm{p}<0.05)$ in the TMR10 and TMR15 than that in TMR5. Concentration of $\mathrm{NH}_{3}-\mathrm{N}$ was highest $(\mathrm{p}<0.05)$ in the TMR10 followed by TMR15 and TMR5. Total volatile fatty acid was decreased $(\mathrm{p}<0.05)$ with increased cutting height. The digestibility of DM and neutral detergent fiber were highest $(p<0.05)$ in TMR15, than those in TMR5 and TMR10, whereas acid detergent fiber digestibility was higher $(p<0.05)$ in TMR5 than that in TMR10. The results showed that increasing cutting height, at least up to 10 to $15 \mathrm{~cm}$, of whole crop barley forage at harvest (Yuyeon) may be beneficial for making silage for TMR formulation and increasing digestibility of DM and NDF. (Key Words: Aerobic Stability, Barley Silage, Cutting Height, Digestibility, Hanwoo Heifer)
\end{abstract}

\section{INTRODUCTION}

The forages for feeding cattle in South Korea comprises rice straw (36\%), cultivated forage crop (44\%), and imported forage (20\%) (MIFAFF, 2011). Except for rice straw that is low quality forage, barley as winter forage occupies the largest share of the domestic forage production. Therefore, improvement of nutritional quality of barley forage may help to increase animal productivity and thus farm profitability. Increasing cutting height at harvest is one of the good options

\footnotetext{
* Corresponding Author: Sam Churl Kim. Tel: +82-55-772-1947, Fax: +82-55-772-1949, E-mail: kimsc@gnu.ac.kr

2 Bangladesh Livestock Research Institute, Savar, Dhaka-1341, Bangladesh.

${ }^{3}$ National Institute of Crop Science, RDA, Suwon 16429, Korea.

${ }^{4}$ Department of Animal Sciences, IFAS, University of Florida, Gainesville, FL 32608, USA.

Submitted Feb. 3, 2016; Revised Apr. 6, 2016; Accepted Apr. 13, 2016
}

for improving nutritional quality of forage or silage. Higher yield of dry matter (DM) and amount of grain from forage (Neylon and Kung, 2003) are considered as quality indicators for whole crop forage or silage. Recently, high digestibility of DM and fiber is also considered indispensable for good quality of forage (Lynch et al., 2015). Above characteristics may be brought into whole crop forage or silage by increasing the cutting height to make whole crop silage (Weller, 1992; Neylon and Kung, 2003; Caetano et al., 2011; Lynch et al., 2015). The potential benefit of increasing cutting height is to reduce the proportion of the fibrous bottom part which has poor digestibility (Caetano et al., 2011). Several studies reported that harvesting the forage at higher cutting height can improve nutritive value of silage and animal performance (Sinclair et al., 2003; Kennington et al., 2005; Wu and Roth, 2005). However, most of studies have been done with corn silage (Neylon and Kung, 2003; Kennington et al., 2005; Wu and Roth, 2005; Caetano et al., 
2011; Lynch et al., 2015) and very rarely with barley. Therefore, the present study was conducted to evaluate effects of different cutting height on chemical composition, fermentation characteristics of whole crop barley (WCB) silage and, in vitro and in vivo nutrient digestibility of total mixed rations (TMR) made up of silages of different cutting height. Our hypothesis was that the increase in cutting height at forage harvest could improve the silage quality and nutrient digestibility of WCB silage.

\section{MATERIALS AND METHODS}

\section{Silage experiment}

Forage production and silage making: The Yuyeon hybrid of barley was used in this experiment, which was developed in Korea by traditional crossbreeding having ruminant palatable awns and better silage quality (Park et al., 2008). The WCB was cultivated at the Animal Research Unit, Gyeongsang National University, Jinju, Korea with a seed rate of $220 \mathrm{~kg} / \mathrm{ha}$. It was planted in October 2011 and harvested in May 2012 at soft dough stage of maturity. The forage was mowed at a height of 5,10 , and $15 \mathrm{~cm}$, from the ground level. Approximately $500 \mathrm{~kg}$ forage from each cutting height was rolled to make round bale with a baler (BWR1-150, JUKAM Machinery Co., Ltd, Suncheon, Korea) followed by wrapping (27 layers of $0.03-\mu \mathrm{m}$ poly-ethylene film) with a wrapper and ensiled in 3 replicates for 100 days. Representative samples of fresh forage were collected from each cutting height before ensiling and stored at $-20^{\circ} \mathrm{C}$ for chemical analysis. After ensiled for 100 days, bales were opened and silages were sub-sampled for subsequent laboratory analysis $(500 \mathrm{~g})$, aerobic stability $(1 \mathrm{~kg})$ determination and storage $\left(-20^{\circ} \mathrm{C}\right)$ for further use in later.

Preparation of silage extract: Twenty grams of fresh silage were homogenized with $200 \mathrm{~mL}$ of sterile doubledistilled water in a blender (HM-1600PB, HANIL Electric Co., Gimpo, Korea) for 30 seconds and then filtered through 2 layers of cheesecloth. The $\mathrm{pH}$ of the silage extract was measured right after extraction, sampled for microbial enumeration and then stored at $-20^{\circ} \mathrm{C}$ for analysis of fermentation products $\left(\mathrm{NH}_{3}-\mathrm{N}\right.$, lactic acid volatile fatty acids) in silages.

Microbial enumeration: The microbial enumeration (yeast, mold, and lactic acid bacteria [LAB]) was done from silage extract immediately after silo opening. A $20 \mathrm{~g}$ sample of silage in $180 \mathrm{~mL}$ of sterile peptone water was homogenized in a blender, filtered through 2 layers of cheese cloth to get silage extract, which was considered as the first dilution and then 10-fold serial dilutions were made. One hundred $\mu \mathrm{L}$ aliquots of 4 consecutive dilutions $\left(10^{-3}\right.$ to $\left.10^{-7}\right)$ were plated in triplicate on selective agar medium for respective microbes. Potato dextrose agar (Difco, Detroit, MI,
USA) was used for the isolation and enumeration of yeast and mold, and lactobacilli MRS agar (Difco, USA) was used for the isolation and enumeration of LAB. The agar plates of $\mathrm{LAB}$ were incubated at $39^{\circ} \mathrm{C}$ for $24 \mathrm{~h}$ in a $\mathrm{CO}_{2}$ incubator (BB15, Thermo Scientific, Waltham, MA, USA) and the agar plates of yeast and mold were incubated at $35^{\circ} \mathrm{C}$ for $24 \mathrm{~h}$ in a general incubator (JS-IN-180, Johnsam Co., Boocheon, Korea).

Aerobic stability: The silage samples were transferred to open-top polyethylene container to determine aerobic stability of silages. Two thermocouple wires were placed to the center of each silages and connected to data loggers (TR$60 \mathrm{CH}$, MORHAN, Hong Kong, China) along with a computer that recorded temperature at every $30 \mathrm{~min}$ for 12 days. The silage containers were covered with 2 layers of cheesecloth to prevent drying and dust in the air. Aerobic stability was determined by the time required to raise the silage temperature $2^{\circ} \mathrm{C}$ above the ambient temperature as suggested by Arriola et al. (2011).

\section{In vitro experiment}

Three TMR were formulated with WCB silages from different cutting heights $(5,10$, and $15 \mathrm{~cm})$ incorporated as forage at 70:30 ratio with concentrate (DM basis). Thus treatments were i) TMR5 (WCB silage from $5 \mathrm{~cm}$ of forage cutting height in the TMR), ii) TMR10 (WCB silage from 10 $\mathrm{cm}$ of forage cutting height in the TMR), and iii) TMR15 (WCB silage from $15 \mathrm{~cm}$ of forage cutting height in the TMR). The ingredient and chemical compositions of three TMR diets are shown in Table 5. Diets were ground in a grinder (Cutting mill, Shinmyung Electric Co., Ltd, Gimpo, Korea), to pass through a $1 \mathrm{~mm}$ screen and incubated with rumen fluid and Van Soest medium (Van Soest et al., 1966) to determine the in vitro dry matter digestibility (IVDMD) and in vitro neutral detergent fiber digestibility (IVNDFD) and rumen fermentation indices. Rumen fluid was collected from two non-pregnant, cannulated Hanwoo heifers fed rice straw and grain mixed at 8:2 ratio. Collection was made $2 \mathrm{~h}$ after morning feeding $(0800 \mathrm{~h})$. The collected rumen fluid was composited, filtered via 2 layers of cheesecloth and mixed with Van Soest medium in a 1:2 ratio. The incubation media was flushed continuously by carbon dioxide gas to maintain anaerobic conditions as suggested by Adesogan et al. (2005). The diet $(0.5 \mathrm{~g})$ and incubation medium $(40 \mathrm{~mL})$ were poured into the incubation bottle (Ankom Technology, Macedon, NY, USA) and then placed into the incubator at $39^{\circ} \mathrm{C}$ for $48 \mathrm{~h}$. Five replications of each treatment were used along with three blanks. After incubation, the sample was transferred to $50 \mathrm{~mL}$ conical tube and the residue was separated from supernatant using centrifuge (Supra 21k, HANIL Electric Corporation, Korea) with rotor (A50S-6C No.6, HANIL Science Industrial, Korea) at 2,568 $\times \mathrm{g}$ for 15 
min. Rumen $\mathrm{pH}, \mathrm{NH}_{3}-\mathrm{N}$ and volatile fatty acid (VFA) were analyzed from the supernatant.

\section{In vivo experiment}

Management of animals: The experiment was carried out at Junga Hanwoo Farm, Jinju, Korea. Animals were cared according to the guidelines of the National Livestock Research Institute (NLRI), Korea. Diets were formulated to meet the nutrient requirements of growing Hanwoo heifer according to the Korean Feeding Standards for Hanwoo cattle developed by NLRI, Rural Development Administration, Ministry of Agriculture and Forestry (Korean Feeding Standard, 2002).

Twelve Hanwoo heifers weighing $375 \pm 46 \mathrm{~kg}$ were randomly assigned into three dietary treatments. Heifers were housed in individual tie-stalls and fed TMR diets as in the in vitro experiment. The diets were provided at a rate of $2.2 \%$ of live weight (Table $8 ; 3.25 \mathrm{~kg}$ ) at 0800 and $1700 \mathrm{~h}$ daily. Free access to clean drinking water was confirmed throughout the experimental period. The trial was continued for 15 days of which first 10 days were for adaptation and last 5 days were for sample collection.

Collection and sampling: The diets were formulated daily and sub-sampled for DM, crude protein (CP), ether extract (EE), crude ash, neutral detergent fiber (NDF), and acid detergent fiber (ADF) analysis. In collection period, the feed refusals and feces were collected and weighed every morning $30 \mathrm{~min}$ before feeding. The feces were collected into covered plastic buckets, weighed, mixed and sub-sampled $(10 \%)$ separately for each animal. At the end of collection period, the samples were composited by animal, mixed and sub-sampled representatively, dried at $65^{\circ} \mathrm{C}$ for $48 \mathrm{~h}$, ground to pass a 1-mm screen using grinder (Cutting Mill, Shinmyung Electric Co., Ltd, Gimpo, Korea) and analyzed for DM, CP, EE, NDF, and ADF. Then DM, CP, EE, NDF, and ADF digestibility was calculated. The samples were stored at $-20^{\circ} \mathrm{C}$ until end of analysis.

\section{Laboratory analysis}

The samples were dried using an oven at $65^{\circ} \mathrm{C}$ for $48 \mathrm{~h}$ to measure the DM content and then the dried samples were ground through a 1-mm screen using a grinder for the analyses of CP, EE, crude ash, NDF, ADF analyses and in vitro digestibility study. Content of $\mathrm{CP}$ was calculated as $\mathrm{N}$ $\times 6.25$, after $\mathrm{N}$ was quantified using $\mathrm{N}$ analyzer (B-324, 412, 435 and 719 S Titrino, BÜCHI, Flawil, Switzerland). The EE was analyzed using the Soxhlet method (AOAC, 1965). Crude ash concentration was determined by burning the sample in a muffle furnace at $550^{\circ} \mathrm{C}$ for $5 \mathrm{~h}$. Contents of NDF and ADF were analyzed according to Van Soest et al. (1991) using $\mathrm{ANKOM}^{200}$ fiber analyzer (Ankom Technology, Macedon, NY, USA). Heat-stable $\alpha$-amylase and sodium sulfite were used in NDF analysis and results were expressed inclusive of ash.

The $\mathrm{pH}$ was measured from silage extract using a $\mathrm{pH}$ meter (SevenEasy pH Meter S20, Mettler Toledo, Greifensee, Switzerland) and the content of $\mathrm{NH}_{3}-\mathrm{N}$ in silage extract was analyzed by distillation using BÜCHI apparatus (B-324, BÜCHI, Flawil, Switzerland) followed by titration with 0.1$\mathrm{N} \mathrm{H}_{2} \mathrm{SO}_{4}$ according to AOAC (1984). Silage extract was centrifuged at $21,500 \times \mathrm{g}$ for $15 \mathrm{~min}$ at $-4^{\circ} \mathrm{C}$ constant temperature. The supernatant was used to measure the lactate and VFA contents by an high-performance liquid chromatography system with a pump (L-2130, HITACHI, Tokyo, Japan), auto sampler (L-2200, HITACHI, Tokyo, Japan), UV detector (L-2400, HITACHI, Japan) and a column (Metacarb 87H, Varian, Middelburg, Netherlands) as described by Adesogan et al. (2004).

\section{Statistical analysis}

The data were analyzed using the general linear model procedure of SAS (2002). Data for microbial enumeration were transformed by $\log _{10}$. The model was $Y_{i j}=\mu+T_{i}+e_{i j}$, where $Y_{i j}=$ response variable, $\mu=$ overall mean, $\mathrm{T}=$ effect of treatment $\mathrm{i}$, and $e_{i j}=$ error effect. Tukey's test was performed to differentiate means. Significance was declared at $\mathrm{p} \leq 0.05$.

\section{RESULTS}

\section{Silage experiment}

The DM content of fresh WCB before ensiling was increased $(p<0.05)$ with the increase in cutting height, while NDF and ADF contents decreased $(p<0.05)$ (Table 1$)$. The EE content in 10 and $15 \mathrm{~cm}$ of cutting height increased $(p<0.05)$, but CP and crude ash were remain unaffected ( $>0.05)$ by increasing cutting height. After 100 days of ensiling, the DM, CP, and Crude ash were unaffected ( $p>0.05)$ by cutting height (Table 2). The EE concentration was increased $(\mathrm{p}<0.05)$ while NDF and ADF concentration was decreased $(\mathrm{p}<0.05)$ by increasing cutting height. The $\mathrm{pH}$ of silage was lower $(\mathrm{p}<0.05)$ in $5 \mathrm{~cm}$, but not different between

Table 1. Chemical composition of barley silage before ensiling (\%, DM)

\begin{tabular}{lcccc}
\hline \multirow{2}{*}{ Items } & \multicolumn{3}{c}{ Cutting height $^{1}(\mathrm{~cm})$} & \multirow{2}{*}{ SEM } \\
\cline { 2 - 4 } & 5 & 10 & 15 & \\
\hline Dry matter & $33.8^{\mathrm{b}}$ & $33.9^{\mathrm{a}}$ & $34.6^{\mathrm{a}}$ & 0.285 \\
Crude protein & 8.61 & 8.61 & 8.64 & 0.052 \\
Ether extract & $2.45^{\mathrm{b}}$ & $3.30^{\mathrm{a}}$ & $3.23^{\mathrm{a}}$ & 0.149 \\
Crude ash & 9.13 & 9.13 & 9.12 & 0.017 \\
Neutral detergent fiber & $57.9^{\mathrm{a}}$ & $57.4^{\mathrm{ab}}$ & $56.0^{\mathrm{b}}$ & 0.588 \\
Acid detergent fiber & $33.9^{\mathrm{a}}$ & $33.4^{\mathrm{ab}}$ & $32.8^{\mathrm{b}}$ & 0.432 \\
\hline
\end{tabular}

DM, dry matter; SEM, standard error mean.

${ }^{1}$ Barley silage had been harvested at 5,10 , and $15 \mathrm{~cm}$ of cutting height from the field, respectively.

a,b Means in the same row with different superscripts differ significantly $(\mathrm{p}<0.05)$. 
Table 2. Chemical composition of barley silage ensiled for 100 days $(\%, D M)$

\begin{tabular}{lcccc}
\hline \multirow{2}{*}{ Items } & \multicolumn{3}{c}{ Cutting height $^{1}(\mathrm{~cm})$} & \multirow{2}{*}{ SEM } \\
\cline { 2 - 4 } & 5 & 10 & 15 & \\
\hline Dry matter & 30.6 & 30.9 & 30.6 & 0.996 \\
Crude protein & 9.04 & 9.02 & 9.02 & 0.016 \\
Ether extract & $3.34^{\mathrm{c}}$ & $3.57^{\mathrm{b}}$ & $3.71^{\mathrm{a}}$ & 0.074 \\
Crude ash & 10.2 & 9.00 & 9.00 & 1.376 \\
Neutral detergent fiber & $52.4^{\mathrm{a}}$ & $52.0^{\mathrm{ab}}$ & $52.6^{\mathrm{b}}$ & 0.363 \\
Acid detergent fiber & $31.0^{\mathrm{a}}$ & $30.6^{\mathrm{ab}}$ & $30.4^{\mathrm{b}}$ & 0.301 \\
\hline
\end{tabular}

DM, dry matter; SEM, standard error mean.

${ }^{1}$ Barley silage had been harvested at 5,10 , and $15 \mathrm{~cm}$ of cutting height from the field, respectively.

a,b Means in the same row with different superscripts differ significantly $(\mathrm{p}<0.05)$.

10 and $15 \mathrm{~cm}$ of cutting height (Table 3). The content of lactate and lactate to acetate ratio were increased $(p<0.05)$ in $5 \mathrm{~cm}$ of cutting height, whereas the acetate content was higher $(\mathrm{p}<0.05)$ in 10 and $15 \mathrm{~cm}$ than that of $5 \mathrm{~cm}$ cutting height. The concentration of $\mathrm{NH}_{3}-\mathrm{N}$ in 100 days silage was not affected ( $p>0.05)$ by increasing cutting height. Aerobic stability was greater $(\mathrm{p}<0.05)$ in silages of 10 and $15 \mathrm{~cm}$ of cutting height, whereas yeast, mold and LAB counts were not affected ( $p>0.05$ ) by cutting height (Table 4$)$.

\section{In vitro and in vivo experiment}

The ingredient compositions of concentrate mixture used in different TMR are presented in Table 5 and the ingredients and chemical compositions of formulated TMRs are illustrated in Table 6. There were no differences $(p>0.05)$ in contents of DM, CP, EE, and crude ash in different TMRs used as treatments. On the other hand, NDF and ADF were found to be decreased $(\mathrm{p}<0.05)$ in the TMRs containing silages from higher cutting heights (Table 6). The concentrations of NDF vs ADF in TMR5, TMR10, and TMR 15 were observed as $51.9 \%$ vs $27.8 \%, 50.9 \%$ vs $27.4 \%$, and $50.1 \%$ vs $26.9 \%$, respectively.

The in vitro digestibility and rumen fermentation indices

Table 3. Fermentation indices of barley silage ensiled for 100 days

\begin{tabular}{lcccc}
\hline \multirow{2}{*}{ Items } & \multicolumn{3}{c}{ Cutting height ${ }^{1}(\mathrm{~cm})$} & \multirow{2}{*}{ SEM } \\
\cline { 2 - 4 } & 5 & 10 & 15 & \\
\hline $\mathrm{pH}$ & $3.86^{\mathrm{b}}$ & $4.00^{\mathrm{a}}$ & $4.02^{\mathrm{a}}$ & 0.045 \\
$\mathrm{NH}_{3}-\mathrm{N}(\%$ of DM) & 0.08 & 0.09 & 0.09 & 0.005 \\
$\mathrm{NH}_{3}-\mathrm{N}(\%$ of total N) & 5.84 & 5.81 & 5.85 & 0.190 \\
Volatile fatty acid (\% of DM) & & & & \\
$\quad$ Lactate & $6.31^{\mathrm{a}}$ & $5.53^{\mathrm{b}}$ & $5.51^{\mathrm{b}}$ & 0.117 \\
$\quad$ Acetate & $1.28^{\mathrm{b}}$ & $1.43^{\mathrm{a}}$ & $1.44^{\mathrm{a}}$ & 0.017 \\
$\quad$ Lactate:acetate ratio & $4.93^{\mathrm{a}}$ & $3.87^{\mathrm{b}}$ & $3.83^{\mathrm{b}}$ & 0.057 \\
\hline
\end{tabular}

DM, dry matter; SEM, standard error mean.

${ }^{1}$ Barley silage had been harvested at 5,10 , and $15 \mathrm{~cm}$ of cutting height from the field, respectively.

a,b Means in the same row with different superscripts differ significantly $(\mathrm{p}<0.05)$.
Table 4. Aerobic stability and microbial growth of barley silage ensiled for 100 days

\begin{tabular}{lcccc}
\hline \multirow{2}{*}{ Items } & \multicolumn{3}{c}{ Cutting height $^{1}(\mathrm{~cm})$} & \multirow{2}{*}{ SEM } \\
\cline { 2 - 4 } & 5 & 10 & 15 & \\
\hline Aerobic stability $(\mathrm{h})$ & $139.3^{\mathrm{b}}$ & $278.3^{\mathrm{a}}$ & $270.5^{\mathrm{a}}$ & 17.86 \\
Microbes $(\log 10 \mathrm{cfu} / \mathrm{g})$ & & & & \\
$\quad$ Yeast & 2.76 & 2.34 & 2.42 & 0.582 \\
$\quad$ Mold & 3.43 & 3.21 & 3.19 & 0.285 \\
Acid bacteria & 6.27 & 6.58 & 6.21 & 0.299 \\
\hline
\end{tabular}

SEM, standard error mean.

${ }^{1}$ Barley silage had been harvested at 5,10 , and $15 \mathrm{~cm}$ of cutting height from the field, respectively.

${ }^{a, b}$ Means in the same row with different superscripts differ significantly $(\mathrm{p}<0.05)$.

are described in Table 7. The IVDMD was higher $(\mathrm{p}<0.05)$ in the TMR5 (47.9\%) and TMR10 (48.8\%) than that in TMR15 $(46.3 \%)$, whereas IVNDFD was higher $(\mathrm{p}<0.05)$ in the TMR10 (42.9\%) and TMR15 (43.5\%) than that in TMR5 $(38.7 \%)$. The $\mathrm{pH}$ was lower $(\mathrm{p}<0.05)$ in TMR10 (6.98) than in the others, but there were no differences between TMR5 (7.06) and TMR15 (7.00). Concentration of $\mathrm{NH}_{3}-\mathrm{N}(\mathrm{mg} / 100$ $\mathrm{mL}$ ) was highest $(\mathrm{p}<0.05)$ in the TMR10 (34.8) followed by TMR15 (33.6) and TMR5 (27.5). Total VFA was decreased $(\mathrm{p}<0.05)$ with increased cutting height $(62.7,59.7$, and 53.3 $\mathrm{mM} / \mathrm{L}$ in TMR5, TMR10, and TMR15, respectively). Molar proportions (\%) of acetate, butyrate and acetate to propionate ratio were highest $(\mathrm{p}<0.05)$ in TMR5 $(58.6,9.14$ and 2.59, respectively). The valerate was increased $(\mathrm{p}<0.05)$ in TMR 10 and propionate concentration was increased $(\mathrm{p}<0.05)$ in TMR 10 and TMR5.

Table 5. Composition of concentrate mixed into the TMR using the in vitro and in vivo experiment $(\%, \mathrm{DM})$

\begin{tabular}{lc}
\hline Ingredient & $\%$ \\
\hline Corn meal & 15.0 \\
Barley meal & 9.00 \\
Soybean meal & 12.5 \\
Rice bran & 14.6 \\
Wheat bran & 19.0 \\
Corn gluten feed & 9.50 \\
Soy bean hull & 8.30 \\
Corn hull & 0.50 \\
Corn cob & 8.00 \\
Corn gluten meal & 1.00 \\
Salt dehydrated & 0.40 \\
Molasses & 1.50 \\
Vitamin and mineral premix & ${ }^{1}$ \\
\hline
\end{tabular}

TMR, total mixed rations; DM, dry matter.

${ }^{1}$ One kilogram of the diet contained the following: vitamin A, 450,000 IU; vitamin $\mathrm{D}_{3}$ 350,000 IU; vitamin E, 20,000 IU; vitamin $\mathrm{K}_{3}, 500 \mathrm{mg}$; vitamin $\mathrm{B}_{1}, 300 \mathrm{mg}$; vitamin $\mathrm{B}_{12}, 15 \mathrm{mg}$; pantothenic acid, $50 \mathrm{mg}$; niacin, $20 \mathrm{mg}$; biotin, $20 \mathrm{mg}$; folic acid, $10 \mathrm{mg}$; $\mathrm{FeSO}_{4}, 4,000 \mathrm{mg} ; \mathrm{CoSO}_{4}, 100 \mathrm{mg}$; $\mathrm{CuSO}_{4}$, 5,000 mg; $\mathrm{MnSO}_{4}, 2,500 \mathrm{mg} ; \mathrm{ZnSO}_{4}, 2,000 \mathrm{mg}$; I, $500 \mathrm{mg}$; $\mathrm{Se}(\mathrm{Na}), 100$ mg. 
Table 6. Ingredients and chemical composition of TMR using in vitro and in vivo experiment ${ }^{1}(\%, \mathrm{DM})$

\begin{tabular}{|c|c|c|c|c|}
\hline & TMR5 & TMR10 & TMR15 & SEM \\
\hline \multicolumn{5}{|l|}{ Ingredient } \\
\hline $\begin{array}{l}\text { Barley silage } \\
(5 \mathrm{~cm} \text { of cutting height })\end{array}$ & 70 & & & \\
\hline $\begin{array}{l}\text { Barley silage } \\
(10 \mathrm{~cm} \text { of cutting height })\end{array}$ & & 70 & & \\
\hline $\begin{array}{l}\text { Barley silage } \\
(15 \mathrm{~cm} \text { of cutting height })\end{array}$ & & & 70 & \\
\hline Concentrate & 30 & 30 & 30 & \\
\hline \multicolumn{5}{|l|}{ Chemical composition } \\
\hline Dry matter & 38.7 & 38.2 & 38.2 & 0.679 \\
\hline Crude protein & 13.3 & 13.4 & 13.3 & 0.089 \\
\hline Ether extract & 3.25 & 3.30 & 3.23 & 0.153 \\
\hline Crude ash & 10.8 & 10.7 & 10.4 & 0.189 \\
\hline Neutral detergent fiber & $51.9^{\mathrm{a}}$ & $50.9^{\mathrm{ab}}$ & $50.1^{\mathrm{b}}$ & 0.283 \\
\hline Acid detergent fiber & $27.8^{\mathrm{a}}$ & $27.4^{\mathrm{ab}}$ & $26.9^{\mathrm{b}}$ & 0.182 \\
\hline \multicolumn{5}{|c|}{$\begin{array}{l}\text { TMR, total mixed rations; DM, dry matter; SEM, standard error mean. } \\
{ }^{1} \text { TMR5, TMR10, and TMR } 15 \text { means TMR based on barley silage had been } \\
\text { harvested at } 5,10 \text {, and } 15 \mathrm{~cm} \text { of cutting height from the field, respectively. } \\
\text { a,b Means in the same row with different superscripts differ significantly } \\
(\mathrm{p}<0.05) \text {. }\end{array}$} \\
\hline
\end{tabular}

Feed intakes and apparent total tract digestibility of nutrients in heifers are described in Table 8. Feed intakes and the digestibility of $\mathrm{CP}$ were not affected ( $\mathrm{p}>0.05)$ by TMRs. The digestibility of DM and NDF were higher $(\mathrm{p}<0.05)$ in TMR15 (61.5\% and 58.6\%), compared to those in TMR5 $(56.5 \%$ and $49.3 \%)$ and TMR10 (57.8\% and 51.0\%), whereas ADF digestibility was higher $(\mathrm{p}<0.05)$ in TMR5 (45.5\%) than that in TMR10 (40.7\%). The EE digestibility was increased $(p<0.05)$ with the increase in cutting height.

Table 7. Effect of total mixed ration with barley silage on in vitro digestibility and rumen fermentation indices ${ }^{1}$

\begin{tabular}{lcccc}
\hline & TMR5 & TMR10 & TMR15 & SEM \\
\hline IVDMD (\% of DM) & $47.9^{\mathrm{a}}$ & $48.8^{\mathrm{a}}$ & $46.3^{\mathrm{b}}$ & 1.267 \\
IVNDFD (\% of DM) & $38.7^{\mathrm{b}}$ & $42.9^{\mathrm{a}}$ & $43.5^{\mathrm{a}}$ & 0.407 \\
$\mathrm{pH}$ & $7.06^{\mathrm{a}}$ & $6.98^{\mathrm{b}}$ & $7.00^{\mathrm{a}}$ & 0.034 \\
$\mathrm{NH}_{3}-\mathrm{N}(\mathrm{mg} \mathrm{N} / 100 \mathrm{~mL})$ & $27.5^{\mathrm{c}}$ & $34.8^{\mathrm{a}}$ & $33.6^{\mathrm{b}}$ & 0.330 \\
Total VFA (mM/L) & $62.7^{\mathrm{a}}$ & $59.7^{\mathrm{b}}$ & $53.3^{\mathrm{c}}$ & 0.607 \\
Acetate (\% of molar) & $58.6^{\mathrm{a}}$ & $52.7^{\mathrm{b}}$ & $52.5^{\mathrm{b}}$ & 1.133 \\
Propionate (\% of molar) & $22.6^{\mathrm{b}}$ & $31.8^{\mathrm{a}}$ & $31.6^{\mathrm{a}}$ & 0.435 \\
Iso-butyrate (\% of molar) & 2.12 & 2.08 & 1.97 & 0.114 \\
Butyrate (\% of molar) & $9.14^{\mathrm{a}}$ & $7.49^{\mathrm{b}}$ & $6.84^{\mathrm{b}}$ & 0.531 \\
Iso-valerate (\% of molar) & $3.88^{\mathrm{a}}$ & $3.31^{\mathrm{b}}$ & $3.32^{\mathrm{b}}$ & 0.159 \\
Valerate (\% of molar) & $2.82^{\mathrm{b}}$ & $3.10^{\mathrm{a}}$ & $2.54^{\mathrm{c}}$ & 0.065 \\
Acetate:propionate ratio & $2.59^{\mathrm{a}}$ & $1.66^{\mathrm{b}}$ & $1.66^{\mathrm{b}}$ & 0.043
\end{tabular}

SEM, standard error mean; IVDMD, in vitro dry matter digestibility; IVNDFD, in vitro neutral detergent fiber digestibility.

${ }^{1}$ TMR5, TMR10, and TMR 15 means TMR based on barley silage had been harvested at 5,10 , and $15 \mathrm{~cm}$ of cutting height from the field, respectively. a,b,c Means in the same row with different superscripts differ significantly $(\mathrm{p}<0.05)$.

\section{DISCUSSION}

\section{Silage experiment}

The increased DM content of fresh forages with the increase in cutting height in this study is related to the higher DM content of the upper part of WCB compared to the lower part. The grain and spike in the upper part in WCB contributed higher DM content (Ji et al., 2007). Similarly, whole crop wheat (446 vs $477 \mathrm{~g} / \mathrm{kg}$ ) and corn $(33.9 \%$ vs $41.5 \%$ ) were also reported to have higher DM content with higher cutting height compared to the lower cutting height (Neylon and Kung, 2003; Sinclair et al., 2003). However, the difference in DM content in fresh forage due to cutting height difference before ensiling did not persist after ensiling (Table 2). The CP, NDF, and ADF concentration of barley forage was different from the values reported by Yun et al. (2009) with same barley hybrid, which might be due to different soil characteristics and harvesting stage of barley forage (Ji et al., 2007; Song et al., 2011). The decreased NDF and ADF content of both forage and silage with increasing cutting height was in agreement with most other previous studies. Walsh et al. (2008) reported a decrease in NDF (465 vs 437 $\mathrm{g} / \mathrm{kg}$ ) and ADF (230 vs $194 \mathrm{~g} / \mathrm{kg}$ ) content when increasing cutting height of barley forage. Sinclair et al. (2003) reported that increasing cutting height of whole crop wheat reduced the NDF content (433 vs $384 \mathrm{~g} / \mathrm{kg}$ ). In case of whole plant corn, the NDF content was numerically decreased by cutting height, whereas ADF content (25.3\% vs $23.4 \%$ ) was reduced significantly (Neylon and Kung, 2003; Lynch et al., 2015).

Lactate has the major role in lowering $\mathrm{pH}$ of silage (Shaver, 2003; Zahiruddini et al., 2004). The pH was lowest in $5 \mathrm{~cm}$ of cutting height in this study because of the higher lactate content in that silage. Oude Eferink et al. (2001) reported that it is possible to convert lactate to acetate under anaerobic conditions. Through unknown mechanisms, lactate was converted to acetate in the higher cutting height silages. As a result, concentration of acetate increased in 10 and $15 \mathrm{~cm}$ of cutting height than $5 \mathrm{~cm}$ of cutting height.

Table 8. Digestibility of total mixed ration with barley silage on Hanwoo heifers ${ }^{1}$ (DM basis)

\begin{tabular}{lcccc}
\hline & TMR5 & TMR10 & TMR15 & SEM \\
\hline Feed intakes (kg/d) & 3.25 & 3.25 & 3.25 & \\
Digestibility (\%) & & & & \\
$\quad$ Dry matter & $56.5^{\mathrm{b}}$ & $57.8^{\mathrm{b}}$ & $61.5^{\mathrm{a}}$ & 0.981 \\
Crude protein & 56.0 & 55.8 & 55.4 & 1.040 \\
Ether extract & $73.0^{\mathrm{c}}$ & $78.0^{\mathrm{b}}$ & $80.2^{\mathrm{a}}$ & 0.890 \\
Neutral detergent fiber & $49.3^{\mathrm{b}}$ & $51.0^{\mathrm{b}}$ & $58.6^{\mathrm{a}}$ & 1.109 \\
Acid detergent fiber & $45.5^{\mathrm{a}}$ & $40.7^{\mathrm{b}}$ & $41.9^{\mathrm{ab}}$ & 1.021 \\
\hline
\end{tabular}

SEM, standard error mean.

${ }^{1}$ TMR5, TMR10, and TMR15 means TMR based on barley silage had been harvested at 5,10, and $15 \mathrm{~cm}$ of cutting height from the field, respectively.

${ }^{a, b}$ Means in the same row with different superscripts differ significantly $(\mathrm{p}<0.05)$. 
Aerobic stability can be improving via the growth inhibition of yeast and mold in silage (Weissbach, 1996). Acetate is one of the antifungal factors for inhibition of yeast and mold (Courtin and Spoelstra, 1990). The yeast and mold counts were not affected in this study at the day of silo opening. However, the increased concentration of acetate in 10 and 15 $\mathrm{cm}$ silage might have inhibited yeast and mold growth and thereby increased aerobic stability in those silages. This result was in agreement with other barley studies (Kung and Ranjit, 2001; Taylor et al., 2002).

\section{In vitro and in vivo experiment}

The decreased concentration of NDF and ADF in TMR (Table 6) with the incorporation of barley silages of increased cutting height is directly related to the chemical composition of respective silages. Silage was incorporated into the TMR at a rate of $70 \%$ (DM basis) while the concentrate mixture was same for all TMRs. Therefore, the fiber concentration of TMRs was dominated by the composition of silages. Weller et al. (1995) reported a decrease in ADF content of silage with the increase of forage cutting height.

It is commonly found that increasing cutting height leads to increase digestibility of whole crop silage due to the proportionate reduction of the fibrous lower part of the plant (Tolera and Sundstøl, 1999) and an increase in the grain portion (Weller et al., 1995). Variety specific increase in IVDMD of maize silage with increased cutting height was reported by Bernard et al. (2004). However, in the present study, the IVDMD was observed lowest in TMR15, which contained the silage of highest $(15 \mathrm{~cm})$ cutting height. However, contrasting results in total tract apparent digestibility of DM in Hanwoo heifers was found in in vivo study (Table 8) compared to in vitro. Thus the DM digestibility from in vivo study was in agreement with previous findings (Bernard et al., 2004). The reason for increased NDF digestibility in TMR15 both in in vitro and in vivo experiment may be related to the increased portion of grains in that treatment. Usually grains contain more digestible nutrients than that in roughage. The reason for increased total tract apparent digestibility of ADF in TMR5 is not clear. However, as effects of cutting height on digestibility may also affected by varietal difference (Bernard et al., 2004), it may happen that fibers from the lower portion of Yuyeon barley forage are also easily digestible. Future study is needed to find digestibility of different nutrients from different portions of Yuyeon barley for a better explanation. In agreement with the present study, increasing cutting height of wheat or barley did not affect feed intake (DM intake) as reported previously (Sinclair et al., 2003; Walsh et al., 2008).

The higher production of total VFA, acetate and butyrate in TMR5 may be related to the higher IVDMD in this treatment. With the increase in cutting height, a shift to increase propionate production was (in TMR10 and TMR15) observed, that might be partially due to the increased IVNDFD in those treatments. France and Dijkstra (2005) reported when high sugar content exists in the rumen, there is a shift of fermentation pattern from acetate to propionate, and in most of cases, acetate to propionate ratio was decreased by increased propionate. Decreased acetate to propionate ratio in TMR10 and TMR15 after in vitro incubation is therefore in agreement with the above statement.

\section{CONCLUSION}

Present study revealed that increasing cutting height increased DM concentration in harvested forage, which, however, was not observed in the silage after 100 day of ensiling. Fiber concentration in terms of ADF and NDF was decreased both in harvested forage and silage. A dramatic increase in aerobic stability of silage was achieved by increasing cutting height, which has great importance when the silage is incorporated into TMR. Significant improvement was observed in DM and NDF digestibility in the TMR incorporated with silage of higher cutting height $(15 \mathrm{~cm})$. Considering all above findings, it can be concluded that increasing cutting height, at least up to $10-15 \mathrm{~cm}$, of WCB forage at harvest (Yuyeon) may be beneficial for making silage for TMR formulation and increasing digestibility of DM and NDF.

\section{CONFLICT OF INTEREST}

We certify that there is no conflict of interest with any financial organization regarding the material discussed in the manuscript.

\section{ACKNOWLEDGMENTS}

This work was carried out with the support of "Cooperative Research Program for Agriculture Science \& Technology Development (Project No. PJ011012032016)" Rural Development Administration, Republic of Korea.

\section{REFERENCES}

Archer, J. A., E. C. Richardson, R. M. Herd, and P. F. Arthur. 1999. Potential for selection to improve efficiency of feed use in beef cattle: a review. Aust. J. Agric. Res. 50:147-162.

Arriola, K. G., S. C. Kim, C. R. Staples, and A. T. Adesogan. 2011. Effect of applying bacterial inoculants containing different types of bacteria to corn silage on the performance of dairy cattle. J. Dairy Sci. 94:3973-3979.

Adesogan, A. T., N. K. Krueger, M. B. Salawu, D. B. Dean, and C. R. Staples. 2004. The influence of treatment with dual-purpose bacterial inoculants or soluble carbohydrates on the fermentation and aerobic stability of bermudagrass. J. Dairy Sci. 87:3407-3416. 
Adesogan, A. T., N. K. Krueger, and S. C. Kim. 2005. A novel, wireless, automated system for measuring fermentation gas production kinetics of feeds and its application to feed characterization. Anim. Feed Sci. Technol. 123-124:211-223.

AOAC (Association of Official Analytical Chemist). 1965. Official Method of Analysis, 10th edn. AOAC, Washington, DC, USA.

AOAC (Association of Official Analytical Chemist). 1984. Official Method of Analysis, 14th edn. AOAC, Washington, DC, USA.

Bernard, J. K., J. W. West, D. S. Trammell, and G. H. Cross. 2004. Influence of corn variety and cutting height on nutritive value of silage fed to lactating dairy cows. J. Dairy Sci. 87:2172-2176.

Caetano, H., M. D. S. de Oliveira, J. E. de Freitas Jr., A. C. de Rêgo, F. P. Rennó, and M. V. de Carvalho. 2011. Evaluation of corn cultivars harvested at two cutting heights for ensilage. R. Bras. Zootec. 40:12-19.

Courtin, M. G. and S. F. Spoelstra. 1990. A simulation model of the microbiological and chemical changes accompanying the initial stage of aerobic deterioration of silage. Grass Forage Sci. 45:153-165.

Eun, J. S. and K. A. Beauchemin. 2006. Supplementation with combinations of exogenous enzymes: Effects on in vitro fermentation of alfalfa hay and corn silage. Final report to Dyadic International Inc. Agriculture and Agrifood Research Centre Report, Lethbridge, Canada.

France, J. and J. Dijkstra. 2005. Volatile fatty acid production. In: Quantitative Aspects of Ruminant Digestion and Metabolism. (Eds. J. Dijkstra, J. M. Forbes, and J. France). CABI Publishing, Wallingford, UK. pp. 157-176.

Ji, H. C., J. I. Ju, and H. B. Lee. 2007. Feed value and yield of whole crop barley varieties depend on organic content. J. Korean Grassl. Sci. 27:263-268.

Kennington, L. R., C. W. Hunt, J. I. Szasz, A. V. Grove, and W. Kezar. 2005. Effect of cutting height and genetics on composition, intake, and digestibility of corn silage by beef heifers. J. Anim. Sci. 83:1445-1454.

KFS (Korean Feeding Standard). 2002. Korean Feeding Standard for Korean Cattle (Hanwoo). National Livestock Research Institute, Rural Development Administration, Ministry for Food, Agriculture, Forestry, and Fisheries, Gwacheon, Korea.

Krueger, N. A. and A. T. Adesogan. 2008. Effects of different mixtures of fibrolytic enzymes on digestion and fermentation of bahiagrass hay. Anim. Feed. Sci. Technol. 145:84-94.

Krueger, N. A., A. T. Adesogan, C. R. Staples, W. K. Krueger, D. B. Dean, and R. C. Littell. 2008. The potential to increase digestibility of tropical grasses with a fungal, ferulic acid esterase enzyme preparation. Anim. Feed Sci. Technol. 145:95108.

Kung, L. Jr. and N. K. Ranjit. 2001. The effect of lactobacillus buchneri and other additives on the fermentation and aerobic stability of barley silage. J. Dairy Sci. 84:1149-1155.

Lynch, J. P., J. Baah, and K. A. Beauchemin. 2015. Conservation, fiber digestibility, and nutritive value of corn harvested at 2 cutting heights and ensiled with fibrolytic enzymes, either alone or with a ferulic acid esterase-producing inoculant. J. Dairy Sci. 98:1214-1224.

MIFAFF. 2011. Counterplan on Increasing of Forage Production. Ministry for Food, Agriculture, Forestry and Fisheries, Gwacheon, Korea. pp. 2-5.

Neylon, J. M. and L. Kung, Jr. 2003. Effects of cutting height and maturity on the nutritive value of corn silage for lactating cows. J. Dairy Sci. 86:2163-2169.

Nsereko, V. L., B. K. Smiley, W. M. Rutherford, A. Spielbauer, K. J. Forrester, G. H. Hettinger, E. K. Harman, and B. R. Harman. 2008. Influence of inoculating forage with lactic acid bacterial strains that produce ferulate esterase on ensilage and ruminal degradation of fiber. Anim. Feed Sci. Technol. 145:122-135.

Oba, M. and M. S. Allen. 1999. Evaluation of the importance of the digestibility of neutral detergent fiber from forage: effects on dry matter intake and milk yield of dairy cows. J. Dairy Sci. 82:589-596.

Oude Elferink, S. J. W. H., J. Kooneman, J. C. Gottschal, S. F. Spoelstra, F. Faber, and F. Driehuis. 2001. Anaerobic conversion of lactic acid to acetic acid and 1, 2-propanediol by Lactobacillus buchneri. Appl. Environ. Microb. 67:125-132.

Park, T. I., O. K. Han, J. H. Seo, J. S. Choi, K. H. Park, and J. G. Kim. 2008. New barley cultivars with improved morphological characteristics for whole crop forage in Korea. J. Korean. Grassl. Forage Sci. 28:193-202.

SAS (Statistical Analysis System) Institute Inc. 2002. SAS/STAT User's Guide: Version 9. SAS Institute Inc., Cary, NC, USA.

Shaver, R. D. 2003. Practical application of new forage quality tests. In: Proceedings of the 6th Western Dairy Management Conference, Reno, NV, USA. pp. 22-25.

Sinclair, L. A., R. G. Wikinson, and D. M. R. Ferguson. 2003. Effects of crop maturity and cutting height on the nutritive value of fermented whole crop wheat and milk production in dairy cows. Livest. Prod. Sci. 81:257-269.

Song, T. H., O. K. Han, S. K. Yun, T. I. Park, and H. J. Kim. 2011. Effect of harvest time on yield and feed value of whole crop barleys with different awn types. J. Korean Grassl. Forage Sci. 31:361-370.

Taylor, C. C., N. J. Ranjit, J. A. Mills, J. M. Neylon, and L. Kung Jr. 2002. The effect of treating whole-plant barley with lactobacillus buchneri 40788 on silage fermentation, aerobic stability, and nutritive value for dairy cows. J. Dairy Sci. 85:1793-1800.

Tolera, A. and F. Sundstøl. 1999. Morphological fractions of maize stover harvested at different stages of grain maturity and nutritive value of different fractions of the stover. Anim. Feed Sci. Technol. 81:1-16.

Van Soest, P. J., J. B. Robertson, and B. A. Lewis. 1991. Methods for dietary fiber, neutral detergent fiber and non-starch polysaccharides in relation to animal nutrition. J. Dairy Sci. 74:3583-3597.

Van Soest, P. J., R. H. Wine, and L. A. Moore. 1966. Estimation of the true digestibility of forages by the in vitro digestion of cell walls. In: Proceedings of the 10th International Grassland Congress. Finish Grassl. Assoc., Helsinki, Finland. pp. 438-441.

Walsh, K., P. O'Kiely, A. P. Moloney, and T. M. Boland. 2008. Intake, digestibility, rumen fermentation and performance of beef cattle fed diets based on whole-crop wheat or barley harvested at two cutting heights relative to maize silage or ad libitum concentrates. Anim. Feed Sci. Technol. 144:257-278.

Weissbach, F. 1996. New developments in crop conservation. In: Proceedings of the 11th International Silage Conference, IGER (Institute of Grassland and Environmental Research), Aberystwyth, UK. pp. 11-25.

Weller, R. F. 1992. The national whole crop cereals survey. In: 

Whole-crop Cereals (Eds. B. A. Stark and J. M. Wilkinson).
Chalcombe Publications, Canterbury, UK. pp. 137-156.

Weller, R. F., A. Cooper, and M. S. Dhanoa. 1995. The selections of winter wheat varieties for whole-crop cereal conservation. Grass Forage Sci. 50:172-177.

$\mathrm{Wu}, \mathrm{Z}$. and G. Roth. 2005. Considerations in managing cutting height of corn silage: Extension publication DAS 03-72. Pennsylvania State University, College Park, MD, USA.
Yun, S. K., T. I. Park, J. H. Seo, K. H. Kim, T. H. Song, K. H. Park, and O. K. Han. 2009. Effect of harvest time and cultivars on forage yield and quality of whole crop barley. J. Korean Grassl. Forage Sci. 29:121-128.

Zahiruddini, H., J. Baah, W. Absalom, and T. A. McAllister. 2004. Effect of an inoculant and hydrolytic enzymes on fermentation and nutritive value of whole crop barley silage. Anim. Feed Sci. Technol. 117:317-330. 